\title{
Shanghai and the Chinese utopia in the early 20th century as presented in "The New Story of the Stone"
}

\section{YIPING WANG - PING ZHU}

DOI: https://doi.org/10.31577/WLS.2021.13.2.2

The novel The New Story of the Stone (新石头记, Xinshitouji [1908] 2016) by Wu Jianren (1866-1910) is one of the most representative utopian works of the late Qing dynasty (1840-1912) at which time China saw unprecedented fundamental social changes. After 1840, China underwent violent internal and external political, economic and military upheavals, and the late Qing government went through a series of major crises and reforms: the two Opium Wars $(1840,1856)$, the signing of the Treaty of Nanking (1842), the Taiping Rebellion (1850-1864), the Westernization Movement (1861), the Sino-French War (1883-1885), the First Sino-Japanese War of 1894-1895, the Hundred Days' Reform of 1898, the Boxer Movement (1900), and many more. Eventually, in 1912, the Qing Dynasty collapsed as the last Chinese dynasty and the Republic of China came into being, ushering in a new era in China. In this period, "the Chinese intellectual framework seemed suddenly inadequate and incompatible with modern global politics" (Isaacson 2017, 9), and the Chinese intelligentsia had to look to the outside and the future for further and wider explorations. The New Story of the Stone came out first in a series in The Southern Gazette (南方 报, Nanfang bao) in 1905 and was published in a single volume in 1908, rightfully serving as a reflection of the radical changes of a period that linked the past as well as the future.

In the midst of prolonged domestic trouble, foreign invasions, and grave social crises, the Chinese intelligentsia "recognized the importance of fiction for its social function. [They] wrote novels to comment on social affairs, and advocated reform and revolution"1 (Ah 2009, 1). The late Qing dynasty saw a boom in fiction. Statistics shows that, from 1901 to 1911,529 novels were written in the modern vernacular Chinese or baihua, of which no less than 50 envisioned a utopian world (Zhou 2012, 67). The New Story of the Stone is widely regarded as "one of the most telling utopian specimens of its time" (Andolfatto 2021, 136). Chuanming Geng (2008) has classified utopias into three types: distant vision, middle vision and close-up vision. The pursuit of the distant type addresses issues like the universal principles for social progress or the ultimate ideal forms of society that human beings can possibly achieve. The middle type mainly, in the form of literature, presents the competitions between specific thoughts, concepts and cultural propositions of a certain era. The close-up type embodies an instinctive response to the national peril. It is more emotionally 
agitating than rational, and normally tinged with ethnocentrism and nationalism. He also argues that The New Story of the Stone is a utopia of distant vision that expresses ultimate concerns of humanity (180-187). However, this paper argues that although The New Story of the Stone shows the transcendental hue of an ideal society, it undoubtedly contains a great deal of the author's observations about his time, country and city, and these are the foundation of the author's construction of that ideal state.

\section{ILLUSION AND MIRROR IMAGE: A DOUBLE UTOPIA}

The title and the protagonist of The New Story of the Stone are derived from the 18th century (mid-Qing dynasty) masterpiece, Cao Xueqin's The Story of the Stone (石头记, Shitouji), more famously known as Dream of the Red Chamber (红楼梦, Hongloumeng [1791] 2008; Eng. trans. 1892). The Story of the Stone, as the pinnacle of Chinese classical fiction, depicted the stories of several aristocratic families. In the story, the protagonist, the young nobleman Jia Baoyu, is the incarnation of a stone left unused by Nüwa, the goddess who restores the vault of heaven in Chinese mythology. The New Story of the Stone, as a sequel to The Story of the Stone, is set in the late Qing dynasty. The novel opens with the explicit remark that it is already the 26th year of Emperor Guangxu's Reign, or 1901 (actually 1900). At this time, as China's traditional agrarian society disintegrated and modern cities emerged, China was changing from seeing itself as the center of the world to viewing the world as composed of individual nations (Wang 2012,39). Under the impact of the West, China had to accept the international system that originated in Western Europe and spread all over the world, and used international laws to emphasize its status as a sovereign state (Wang 2003, 37).

In the context of these changes, the novel borrows the identity of Jia Baoyu from The Story of the Stone, but the character's personality and the world he observes are now essentially different from the mid-Qing period. The new Baoyu represents the aspirations and hopes of an era of social changes in early 20th-century China, as he moves from his aversion to a career in a bureaucratic government in The Story of the Stone to his ambition to "mend heaven" and to "secure the nation and fix the country" in the new story. So the novel begins with the "birth of a new man" who cares about the future of the nation. In a sense, the protagonist is similar to Voltaire's Candide or Goethe's Faust, who travels and explores the world in response to the age of Enlightenment.

Unlike the novels that plainly explain political ideas in the form of utopian literature in the late Qing dynasty, such as The Future of New China (新中国未来记, Xinzhongguo weilaiji, 1902) by the modern politician and thinker Liang Qichao, The New Story of the Stone shows the author's literary technique of building an appealing utopia. Particularly noteworthy is the novel's elaborate multiple symmetrical/asymmetrical structure. Baoyu originally cultivated himself at Qinggengfeng, the Greensickness Peak of the Barren Mountain, but now, he bumps into the prosperous world after "many generations have passed" (Wu 2016, 2). The manner by which Baoyu enters modern China is vaguely explained, but the time and place 
at which he enters are clearly indicated. This is notably influenced by Edward Bellamy's utopian novel Looking Backward: 2000-1887 (1888), which was introduced and widespread in China at the time and in which the protagonist, after a hundred years' slumber, wakes up in Boston in the year 2000 to see a better world. Similarly, Baoyu, begins his new journey in 20th-century Nanjing, and then visits the major Chinese cities like Shanghai, Beijing and Wuhan, hence seeing a "new world".

The New Story of the Stone contains 40 chapters. The first 20 chapters show the Chinese society of the time through Baoyu's travels, mostly in Shanghai, where there is increasing communication and trade with the West. The portrayal of Shanghai reflects the popular aspirations of many Chinese statesmen and scholars at the time for "Chinese learning as the essence and Western learning for application", while at the same time complying with the actual development of Shanghai. The novelty of the "new world" for the protagonist is twofold. On the one hand, Baoyu, who comes from more than a hundred years ago, is awed by the advanced new objects, industries and organizations of the future society, and experiences the wonderful functions of new creations such as matches, electric lamps, phonographs, telegraphs, trains and steamboats. On the other hand, as the "future world" is indistinguishable from the Western civilization, he also encounters Western investment and technology which had been rejected by the Chinese for a long period. Baoyu observes the rise of foreign-funded industries in Shanghai. After 1842, Shanghai was forced to open as a port of entry for foreign trade under the terms of the unequal Treaty of Nanking, and quickly developed into China's most important foreign trade center. The value of Shanghai foreign trade had increased from 74 million to 155 million $\mathrm{HkTl}$ (the customs tael which represented 38.40 grams of pure silver) between 1861 and 1894, and it doubled again between 1895 and 1911 (Bergère 2009, 51). From 1895 to 1911, out of the 91 enterprises that the foreigners opened in China, 41 were located in Shanghai (Zhang 2008, 11). In the mid to late 19th century, there were a number of large foreign firms in the British Concession in Shanghai, such as Jardine and Matheson Company and the Dent Company, and within a few years, the line of foreign hong (the buildings needed for commercial activities) extended right along the curve of the Huangpu River (Bergère 2009, 34). Meanwhile, after the late 19th century, some of the world's leading industrial technologies were even first applied in Shanghai (Zhang 2008, 45). Shanghai was the base of the Westernization Movement in China. For example, Li Hongzhang, a minister of the late Qing dynasty and an important leader of the Westernization Movement, supported the establishment of industrial enterprises in Shanghai, such as the Jiangnan Arsenal and the China Merchants Steam Navigation Company. The author Wu Jianren was born in Guangdong Province and went to Shanghai in 1883 to make a living and stayed there for a long time (Wang 2019, 17). He worked for a long period as a scribe and draughtsman for the Jiangnan Arsenal, the largest armament and shipbuilding enterprise founded in modern China. The novel shows, through the curious eyes of Baoyu, the novelty of matches, tea stoves, telegraphs, modern ships, and even the insurance industry, which had been introduced to China since the late 19th century. It could be argued that, because of the author's special background, his work gives Baoyu, more than most Chinese of the time, a fuller and 
more direct exposure to the new artefacts and technologies created by Western industrial civilization.

It is clear that the author does not intend to deny the advantages of Western material civilization and technology. In the novel, Baoyu's first reaction to the modern equipment and techniques is not to be repellent. Instead he asks: "Why don't we learn to do it ourselves?", "If they can do it, why can't we?" (Wu 2016, 25, 34) Such a stance is largely consistent with the pursuits of the Westernization Movement. In an instance of the novel, when Baoyu visits a Chinese gun factory, he hears the anecdote of Li Hongzhang naming the guns made in the factory "successive quick grabs" (53). It appears that Baoyu has discarded the arrogance of an ancient civilization, and is not self-alienated from modern technology. Rather, he is enthusiastic to understand Western civilization and institutions.

Accordingly, when the novel depicts the Boxer Movement, it is explicitly critical of this extreme xenophobia and radical nationalism. Baoyu is strongly opposed to his relative Xue Pan's joining the Movement. In the novel, Baoyu is almost killed by Wang Weier, a member of the Boxer and a gangster. Baoyu's comments on Wang Weier indicates his view of the Boxer Movement: "Evil and treacherous, heartless and shameless. [...] It seems that the Boxers are all like that. But how could the man in power actually trust them and use them?" (89) Also, the novel emphasizes a stunning fact for the Chinese at the time, "I have thought China is one country, all of the foreign others is another one. [...] Now I understand that there are many of them!" (81) That is to say, the traditional idea of China as unique "heavenly kingdom" was collapsing and people began to recognize a global world in which many nations co-exist and are closely interconnected, and to accept equal relations among all races and nations instead of the hierarchical "heavenly kingdom" as the center of the world. They came to understand the meaning of "nation" as a representation of rights, thus developing a modern nationalism that was different from the traditional national thought (Wang 2003, 183).

In the end of the novel, the Peace Conference of All Nations is held by China, with an aim "to seek peace for all mankind [...]. Every race such as the red, the black and the brown should be treated as equals. [...] Eliminating hegemony and practicing pacifism" (Wu 2016, 229). Based on this philosophy, the ideal world imagined by The Story of the Stone differs from the pre-modern dreams such as Tao Yuanming's isolated paradise "Peach Blossom Land" and Thomas More's Utopia. Wu's utopia shares more similarity with H.G. Wells's Modern Utopia. When the Chinese open their eyes to see the world, the utopia they envisage is no longer based on small, closed communities, but is (obliged to be) grounded in the new situation of interconnectedness between the many nations of the modern world.

However, the equation that "civilization and progress equals foreign (Western European) culture" causes Baoyu's resistance to the possibility of a colonized future China and thus creates a tension in the novel. The author deliberately reduces Baoyu's appreciation of the people and objects of this semi-colonized "brave new world". For example, when Xue Pan, who "adapts smoothly to the changed circumstances" and enjoys his new lifestyle as a "consumer" (Huters 2005, 158), plays a re- 
cord on a phonograph, Baoyu does not show the slightest appreciation, but remarks: "It doesn't sound like a human voice or an animal voice. It's just annoying. It's tasteless to have spent money on this for fun" (Wu 2016, 23). Baoyu is not a techno-conservative. Perhaps the reason for this is that, being in a Chinese city at the forefront of communication with Western civilization, he is intimidated by the full penetration of advanced artefacts into everyday life made possible by modern Western technology. After a visit to a foreign firm in Shanghai, he laments that "out of ten shops, nine sell foreign goods. Our Chinese businesses are gone" (25). Baoyu's comments on certain Western consumer goods may represent the traditional Chinese idea of "fancy tricks", in which elaborate objects are seen as a waste of resources. But more importantly, in his mind, there is a blend of modern technological products, foreign firms, compradors and a highly westernized (colonized) modern city. Thus, the Chinese urban landscape, which combines the advanced technology, international trade and commerce transactions, and the ruler's pandering to foreigners, indicates the backwardness of China and unequal international interactions. This cannot be accepted by the author as the ideal society for China. Therefore, although the novel gives its protagonist a glimpse of a brave new future world, a virtual utopia, it constantly undermines the legitimacy of that society as an ideal state.

How, then, does The New Story of the Stone confront an attractive but problematic "new world" such as Shanghai? This essay argues that the novel wisely adopts what might be called a "mirroring" approach to the construction of a utopia. This mode of creation can be seen, first of all, in the selection of the few major characters in the novel. In Shanghai, for example, Baoyu meets the foreign firm's comprador, Bai Yaolian (homophonic to "shameless" in Chinese). A comprador is the Chinese partner of a foreign merchant, an intermediary in international trading. The novel portrays Bai Yaolian as a fraud who denies Chinese culture, flatters foreigners, and cheats his friends. In contrast, the novel portrays Wu Bohui (homophonic to "Knowall" in Chinese), an instant friend of Baoyu as very knowledgeable about Western culture and modern things. He leads Baoyu on a tour in Shanghai, encourages him to learn English, and eventually saves him from imprisonment. In the novel, $\mathrm{Wu}$ Bohui is the one character who really tries to learn and digest the Western culture, as opposed to Bai Yaolian, who totally rejects Chinese traditions and flatters the foreigners. The author uses a "distorted mirror image" of these two characters: the comprador Bai Yaolian is a negative image that clings with Shanghai, but right next to him is a positive figure, Wu Bohui, whose background and position are similar in every way, but a far more righteous and honest person than the former.

The author also uses this "mirroring" approach to build his utopia, where the same type of people, things, or objects, such as A and B are created. A and B share many similar qualities, but one is clearly superior to the other, and the two form a distorted mirror relationship in contrast. It is the basic technique used in the novel to create a utopia. In the next 20 chapters, the novel designs a much better Civilized World than the westernized Shanghai. In other words, the novel creates an ideal nation based on the illusory utopian Shanghai. That is, outside of the Shanghai Utopia, it constructs a distorted mirror world which corresponds to Shanghai in every re- 
spect. The perfect mirror world is the real utopia. As the novel deliberately mentions, the protagonist carries a "mirror" into modern Chinese society and, after looking deep into the false wonderland, discovers a mirror world that is a true utopia.

\section{THE CIVILIZED WORLD: UTOPIAN IDEAS AND UTOPIAN GEOGRAPHY}

Like John the Savage in the classic anti-utopian novel Brave New World (1932), who finally sees the loss of natural humanity in advanced technology, in the first 20 chapters of The New Story of the Stone, Baoyu, during his travels in Shanghai, Beijing and other cities, gradually recognizes that China in 1900 is a false brave new world. At the end of the 20th chapter, Baoyu is tragically imprisoned and almost murdered for criticizing the views of the Wuchang School superintendent, and realizes that this is a "barbarous country". Baoyu suddenly remembers where he has come from - the Greensickness Peak, a purely fictional and symbolic home. Although Baoyu's travels in The New Story of the Stone have no connection to the Greensickness Peak, his recollections at this point play a key role in threading the whole story. In the first chapter, the protagonist leaves the Greensickness Peak to travel to modern China in an attempt to fulfill his ambition to "mend heaven". But up to the end of the 20th chapter he not only failed to mend heaven, but almost got killed. This failure of himself shows that the seemingly civilized Shanghai is a utopian illusion. It is only after reminiscing about the Greensickness Peak that Baoyu sets out again, in the 21st chapter, and finally sees a truly civilized country. Throughout the whole story, the false utopia and the true utopia are evenly divided into two symmetrical parts, with the Greensickness Peak as the dividing line, forming mirror images of each other, though not identical.

In the latter 20 chapters of the novel, Baoyu is invited by Xue Pan to go to the north in search of the Liberty Village and inadvertently enters the Civilized World. This world is an ideal society with prosperous science and technology and well-developed institutions, and is composed of five main regions: the East, the South, the West, the North, and the Central. As Nathaniel Isaacson puts it, the novel is a strikingly comprehensive version of the failings of the late Qing state, and of utopian yearnings with Confucian characteristics $(2017,62)$. The hallmarks that define the Central region of the Civilized World are the Chinese characters Li (ritual), Yue (music), Wen (culture) and Zhang (order), all of which are highly-regarded qualities in Chinese Confucian society. Baoyu's host in this realm is called Lao Shaonian (Old Youth). Lao Shaonian is the mouthpiece for the author himself. The novel then discusses via Lao Shaonian the question of the political system in the Civilized World, which was a major issue at the time concerning the future of China. As for constitutionalism that China was facing at this time, the author wrote a number of short satirical stories such as “Celebrating Constitutionalism” (庆祝立宪, “Qingzhu lixian”, 1906), “Preparing for Constitutionalism” (预备立宪, “Yubei lixian”, 1906) and “Long Live Constitutionalism”(立宪万岁, “Lixian wansui”, 1907). He does not oppose constitutionalism, but is critical of the pseudo-constitutionalism by the characters of all parties who just change a political title to satisfy their own selfish desires (Ah 2009, 82). The Civilized 
World considers the republican form of government to be the most barbaric. This is perhaps because the author sees party politics and parliamentary politics the same as the much-criticized "clique strife" in the Chinese political tradition. He argues that "numerous parties contradict each other and the government is just like a masterless ghost which only satisfies the wishes of whichever party that flourishes" (Wu 2016, 143). The author seeks an inner "non-self-satisfying" mind as a means of motivating the development of individuals and society. As for the reasons for the introduction of a monarchical system of government, Lao Shaonian emphasizes "moral education" for all, arguing that "if moral education is universal, constitutional government can be abolished" (144). He believes all that is needed is to advocate "[the monarch] loving what his people love and hating what his people hate" as stated in traditional The Great Learning (大学, Daxue, about the 5th c. BCE) (Wu 2016, 144), the classical Confucian text concerning individual moral cultivation and social ideals. Therefore, the author can be reasonably viewed as a representative of "cultural conformism" and "enlightened conservatism" in a period of social transformation in China (Geng 2008, 183-184).

However, the novel's rhetoric about the concept of "Dao" (the Way, or more exactly the Way of Confucius) for an ideal state reveals a contradiction between the author's ideology and his actual vision. In the novel, Baoyu points out that some so-called new phrases such as "reform" were already found in ancient Chinese classics. For instance, in The Book of Songs (诗经, Shijing, about the 6th c. BCE) there is the expression "Although Zhou was an old state, the divine mandate it bore was to reform" (Wu 2016, 98). Wu Jianren not only indicates the legitimacy of reform, but also puts a nation's traditions as the basis for the development of an ideal state. However, while the novel explains the superiority of the traditional Chinese social ideals, the author is also clearly aware that the inescapable theme of the time is to learn from the West to reform China. In other words, on the one hand, the author lacks a deep understanding of and trust in Western constitutional democracy and hopes that the Civilized World will preserve the spirit of traditional Chinese virtues; on the other hand, he finds that a modern civilized state has to assimilate other cultures such as Western political institutions, technologies, concepts of equality, etc. This contradiction leads to some obvious flaws in the design of the Civilized World, such as the parallelism between the monarchy and the actual constitutional democracy. In the novel, although the Civilized World is a system of monarchy, Lao Shaonian makes it clear that, for any countries, before they reach "civilization" (utopia), a constitutional system is better than dictatorship. "With dictatorship, the only government is high above and exerts pressure on the inferiors, and local officials cannot be good ones even if they want to be" (Wu 2016, 144-145).

The Civilized World is supposedly based on the "Way of Confucius", but it has to borrow the experience of Western technological and institutional civilization. Therefore, it is not a utopian system actually instituted on the basis of the traditional Chinese virtues. "No matter how much he emphasizes the underpinning role of quintessence of the Chinese culture, [...] his ideal state is inscribed everywhere with the obvious marks of modernization or westernization, i.e. democra- 
cy and science" (Chen and Wang 2013, 26). Of course, the author is not ignorant of the glaring problem. Instead, he employs an interesting strategy: after proposing the ideas of the Civilized World, he then evades the dilemma in a roundabout way. This is mainly reflected in the choice of utopian locations and in Baoyu's travels after he enters the Civilized World. The novel first devotes several chapters to the basic program of the Civilized World - its social philosophy, and so on, but does not continue to elaborate on the many aforementioned philosophies. Rather, it begins to depict the Civilized World in the form of a Vernean adventurous sci-fi fantasy. From the 26th to the 33rd chapters, Baoyu's observations and experiences are completely transformed as the novel embarks on a lengthy series of exotic adventures that take up nearly a quarter of the novel's total length.

The selection of the geographic space in which the protagonists have their adventures is also interesting: instead of China, or the major European countries of the modern world in the author's mind, the novel depicts places like the African savannah and the undersea world, which were unfamiliar to the Chinese at the time. Baoyu and Lao Shaonian take a flying vehicle for hunting and encounter the hard-to-catch roc, and then arrive in the vast desert, where they, through a world map, compass and stargazing, come to realize it is Africa. The novel details the thrilling journey of chasing and capturing the roc and putting it in the museum in the Civilized World. Then this is followed by an underwater roam in a hunting vessel, which can travel 12,000 miles in one day and night. Baoyu and the others then embark on an underwater journey around the globe. Like the heroes of Verne's Twenty Thousand Leagues Under the Sea (Vingt mille lieues sous les mers: Tour du monde sous-marin, 1869; Eng. trans. 1872), Baoyu witnesses underwater wonders such as a seahorse biting and killing a giant squid, encounters attacks by many large sea loaches, and mermen attacking sailors on a hunting boat. He even sees the legendary fish Tiao (倐), catches sea minks at the South Pole, acquires large pieces of corals, and then goes through a submarine tunnel in Australia.

This section of the novel clearly embodies the feature of some late Qing novels - what David Der-wei Wang calls "science fantasy". The bulk of these writings arise as a consequence of the introduction of Western science fiction, but the genre recapitulates many features characteristic of traditional Chinese fantastic and mythical stories $(1997,253)$. Compared with the utopian novels, or even the other parts of The New Story of the Stone, these adventures are much closer to early 20th-century sci-fi adventures than to the utopian ideas introduced in the preceding pages, and are therefore considered by many critics to be rather odd. Admittedly, the second part of the novel begins with a discussion of the abstract ideas on which the perfect society is based, and then elaborates on the adventures in the wonderland. However, apart from being a means to intrigue readers, there is an important reason for this insertion. That is, since it is far removed from the everyday life of the general public and the normal conventions of utopian fiction, it effectively avoids the need to concretely envisage everyday economic systems, cultural mores, family patterns, children's education, and so on, after stating the idea of a utopian society. Thus, while it does "touch upon the major issue of how traditional culture participates in the con- 
struction of modernity" (Geng 2008, 185), on the whole, in almost half the length of the narration about the utopia, the novel abandons the specific design of political details and commonly-seen characters in utopia, leading the protagonists to temporarily disengage from the perfect society while travelling across continents and around the globe to the untouched wildernesses. By doing so, it avoids the great difficulty of reconciling the ancient and the modern, East and West, idea and practice in a utopia. The novel shows the foundation and frame of a utopia, but fails to give careful scrutiny of the possible contradictions at the deeper level, leaving the unattended major issues like whether the advanced technologies that sustain the utopia can survive in the system of absolute monarchy.

\section{SHANGHAI: A QUASI-UTOPIA}

As mentioned earlier, The New Story of the Stone is a depiction of highly imaginative geographical places, such as the underwater world. But when it comes to the Civilized World, it is not difficult for the reader to notice the features of the particular time and place. The Civilized World can well be a twisted mirror image of Shanghai. The realization of the Civilized World corresponds with a critique of Shanghai. This can be seen from the fact that Baoyu constantly looks back at Shanghai and compares it with the Civilized World as he travels through it. It is hardly possible to understand the Civilized World without taking Shanghai as the original image.

China was reduced to a semi-colony after the 1850s. Port cities like Shanghai relevant to global trade were incorporated into the European colonial project. They show a kind of colonial modernity which is the hybrid offspring of the encounter between margin and periphery in the context of imperial expansion (Isaacson $2017,17,20)$. With foreign concessions as "state within a state" enclaves, Shanghai had a strong colonial overtone. The number of Westerners in Shanghai increased from a few hundred in the mid-19th century to around 15,000 in 1910 (Bergère 2009, 85). The British, Indian, Japanese, French, American and other expatriates in Shanghai controlled the concessions and largely defined the overall social features of Shanghai. In the late 19th century, while the literati and officialdom in Beijing and elsewhere were still ashamed to socialize with the foreigners and opposed to learning foreign languages, there was already a quiet boom in the learning of foreign languages in Shanghai, and wealthy and official families there were allowing their children to receive a Western education (Zhang 2008, 15). The New Story of the Stone also mentions Baoyu's efforts to learn English in Shanghai. It can be argued that many of Shanghai's modern technologies, management styles and political ideas were imported from abroad, and the development of Shanghai as a modern metropolis bore a deep Western imprint (Zhang 2008, 25). At the beginning of the novel, Xue Pan tells Baoyu, who is new to Shanghai, "Shanghai is different from other places for four things, namely, carriage rides, park walks, listening to Chinese operas and visits to brothels, no fifth thing" (Wu 2016, 21-22). It is clear that such entertainment and social activities as horse-drawn carriage running and (Western-style) park strolling has a distinctly Western flavor. "In this foreign Shanghai, painstakingly modeled on the image of the capitals of Europe, residents 
tried to re-create the amusements and way of their own class in their native societies" (Bergère 2009, 93). Clearly, in this novel, Shanghai is a uniquely modern Chinese city with a westernized undercurrent.

The author's mouthpiece Lao Shaonian points out that the foreign colonialists with great military power intimidated, beat and kicked the weak China, although claiming to be civilized. As the historian Marie-Claire Bergère puts it, the foreigners were regarded as models from whom the Chinese borrowed production techniques and economic, social and political systems. However, the acculturation that accompanied such borrowing was rendered the more humiliating by the arrogance of the foreigners and the privileges they enjoyed. "[I]n Shanghai, the customary xenophobia took the form of a modern nationalism that aimed to take up the Western challenge on its own terms: it aspired to economic modernization, material prosperity, and social progress" $(2009,5)$. Therefore, the author of The New Story of the Stone significantly transforms Shanghai's urban landscape into a utopia which is more advanced and magnificent than the westernized Shanghai. For example, in the Civilized World, Baoyu sees artefacts similar to those seen in Shanghai, such as gramophones and electric lights, but they are much more user-friendly. Baoyu also compares the clocks and watches in Shanghai with their improved counterparts in the Civilized World. When Baoyu sees both local products and Western goods in the trading market of the Civilized World, he reflects about feeling overwhelmed by the goods in the foreign shops in Shanghai; but now, after seeing the elegant products of the Civilized World, he finds the foreign goods unbearably vulgar. In another example, Baoyu visits Winterview Park in the Civilized World and compares it to the famous western-styled fashion center in Shanghai, Chang-Su-Ho Garden, which he finds less tasteful than Winterview Park. The novel uses a number of utopian scenarios to belittle and satirize Shanghai of that time. This critical function is common in utopian literature. Meanwhile, this belittling is also cathartic in nature, relieving the author's dissatisfaction with the inequalities he has seen in Shanghai in the process of learning from the outside world and transforming themselves.

Undeniably, the novel associates Shanghai with "civilization", because the Civilized World is actually based on the real-life Shanghai. From the core of the Civilized World radiates the light of Shanghai. There are already many sprouts of the author's ideal "civilization" in Shanghai: the first time Baoyu enters Shanghai, he sees modern industries such as yarn factories, clothing factories, and waterworks. The novel also describes in detail Baoyu's visits to a boiler factory, an iron factory, a gun factory, western-styled houses and parks. It also describes his reading of the new-styled newspapers and magazines, the discussions on gender issues and school education in Shanghai. Obviously, the images of advanced hospitals, factories, museums, naval academies, women's schools, and trading markets in the Civilized World do not derive from the traditions of ancient Chinese civilization, but from the many promising new things the author sees in his long experience of life in Shanghai. For example, Shanghai is home to the earliest museum founded by foreigners in China, the Siccawei Museum, which was founded in 1868 by French Jesuit missionary and zoologist Pierre Marie Heude. 
Since the opening of Shanghai as a port, it has attracted a large number of landed gentry and cultural elites from the southern part of the country, as well as merchants and compradors from Guangdong and Fujian provinces. The author, Wu Jianren, from a declined family of officials in Guangdong province, though had started as a petty clerk, still belonged to an educated group of social and cultural elites. As for these groups, the upheavals brought about by the opening of Shanghai allowed them to find a measure of agreement regarding the idea that change was necessary, as they all intended to make the most of the economic conditions and to assume unprecedented political and social responsibilities (Bergère 2009, 104). It was the observation of China's modernization process and its challenges in the "experimental site" of Shanghai that made people aware of the need for change, and this attracted groups such as Wu's to make serious observations and think deeply about the society of the time. These groups often met and talked in restaurants and teahouses. The New Story of the Stone, for example, mentions Baoyu and Xue Pan's visit to a restaurant in Shanghai and the pungent smell of soot they experienced, which leads to the main concern of the novel - the issue of "civilization" and "barbarism". Baoyu says that he has heard people in Shanghai talk about "civilization and barbarism". They also say that of all the places in China, Shanghai is the most civilized (Wu 2016, 48). Baoyu mentions that Shanghai is "civilized", but in the meantime, suggests, with the symbolic smell, the "smoky" Shanghai is not a perfect place. However, against the backdrop of the collapse of the Qing Dynasty and the need for significant changes, the path of Shanghai's development remained an important source of ideas for Chinese intellectuals at the turn of the century as they explored the way forward. Shanghai flourished from commerce, the capital and technological resources from home and abroad, and was the most important economic center in modern China, as well as an important base for China to absorb various Western scientific, political, economic and cultural ideas. Although Shanghai was not a utopia, the Civilized World was still an imaginative renovation based on the so-called "barbarous and filthy" Shanghai of that time.

In the 12th chapter of The New Story of the Stone, the focus of the novel briefly shifts to Beijing. The local ruffian Wang Weier, who kills the parishioner Yang Shizi (a homonym for "foreign power") in revenge, befriends Xue Pan by chance while in exile in Shanghai. On his return to Beijing, Wang Weier joins the Boxer Rebellion and invites Xue Pan to join him. Baoyu then goes to the capital. In other chapters, the author satirizes the absurdity of the Boxer Rebellion and the lethargy of the officials, with the former claiming to be heavenly soldiers invulnerable to swords and spears. This is followed by the Gengzi Incident, a major historical event that saw the siege of the embassies and consulates and the flight of the imperial family to Shanxi province. It is easy to see that the cities in focus correspond to specific events and corresponding imagery, particularly Shanghai and Beijing, representatives of southern and northern Chinese cities respectively. Although the events mentioned in the novel are based on historical facts, the specific descriptions suggest the author's inclinations. In the 17th chapter, Baoyu, who has undergone historical upheavals and personal hardships, returns to Shanghai from Beijing and listens to a public lecture 
on state affairs with Wu Bohui in Chang-Su-Ho Garden. Here, when Baoyu talks to Bohui about the foolishness of the Boxers and the decrepitude and incompetence of the Qing court that he saw in Beijing, Bohui states that "the capital [...] is conservative and closed. Shanghai can be called open [...]" (93). In fact, the reformation areas depicted in the novel are southern cities: Nanjing, Shanghai and Wuchang (though the author's intention is to criticize the reformers), while the major northern cities like Tianjin and Beijing are either mere brief transitional localities or are associated with people and events that the author disparages, for example, the Boxer Rebellion and Wang Weier. This juxtaposition of north and south may come from the author's inclination to portray the southern cities he is familiar with and reveals the fact that many of the major reforms in China in modern times began in the various southern port cities. This also reinforces a binary of the "reform-conservatism" stereotype of the South and the North roughly divided by the Yangtze River.

At the end of the novel, the false utopia (Shanghai) and the real utopia (the Civilized World) are merged in the protagonist's dream. In the final chapter of the novel, Baoyu dreams a dream in the Civilized World: he returns from the Civilized World to Shanghai. He learns that by this time China has had a new governmental system improved with evolutions rather than radical revolutions. The constitution that China had acquired on its visits to foreign countries absorbed the strength of the systems abroad, combined them with its own characteristics and opened up new horizons. Shanghai had taken back the extraterritoriality, developed its industry and enjoyed economic prosperity. "Shopping malls were opened in downtown and Nanshi, all the way to the Jiangnan Arsenal. Shops in Wusong are full of people, and conference halls were built in Pudong" (Wu 2016, 228). In the World Exposition held in Shanghai, "Countries were given places and they changed their venues to display various goods. Provinces of China also built their own venues, and there was a great deal of excitement and an inexhaustible amount of strange and exotically-manufactured goods" (228). This dream of the author came true 100 years later, in 2010, when Shanghai hosted the World Exposition, a showcase of national power. After waking up from his dream, Baoyu leaves the Civilized World, and his avatar, the Stone falls into the mountains, where Lao Shaonian discovers The New Story of the Stone engraved on it and passes it on to future generations.

In short, The New Story of the Stone explores, in the form of utopian fiction, the major conceptual and institutional issues of Chinese society at the time, such as "civilization/barbarism", "constitutionalism", and "reform/revolution". The allusion to reality reveals the author's utopian impulse and fervent imagination at a critical time of national transformation. Although this utopian imagination is somewhat abstract, it is undoubtedly based on concrete urban archetypes, such as the quasi-utopian Shanghai. As Theodore Huters' comment on Wu Jianren's other novel Bizarre Happenings Eyewitnessed over Two Decades (二十年目睹之怪现状, Ershinian Mudu zhi guaixianzhuang, 1906; Eng. trans. 1975) in which Shanghai is also the thematic foci, Wu Jianren "had voiced a sense of how the new urban space of Shanghai had come to represent the modern transformations that were taking place rapidly in China by the late Qing" $(2005,153)$. The utopia in the novel represents an integrated 
expression of both social criticism and social ideals. With its emphasis on the abstract ideas of utopia, its territorial fictionalization and its real geographical locations, the novel creates a unique utopia that the Chinese society could best hope to conceive of at the beginning of the 20th century, and by this utopia the novel arrives at the learning from the Western civilization and the imaginative transcendence of it at the same time.

\section{NOTES}

1 All translations from the Chinese are by the present authors unless otherwise noted.

\section{LITERATURE}

Ah, Ying. 2009. Wanqing xiaoshuoshi [A History of the Late Qing Fiction]. Nanjing: Jiangsu Literature and Art Publishing House.

Andolfatto, Lorenzo. 2021. “Utopia/Wutuobang as a Travelling Marker of Time.” The Historical Journal 1, 64: 121-138.

Bergère, Marie-Claire. 2009. Shanghai: China's Gateway to Modernity. Trans. by Janet Lloyd. Stanford, CA: Stanford University Press.

Cao, Xueqin. [1791] 2008. Hongloumeng [Dream of the Red Chamber]. Beijing: People’s Literature Publishing House.

Chen, Wenxin, and Tongzhou Wang. 2013. "Xinshitouji yu qingmo minchu de wenhua bianqian" [The New Story of the Stone and the Culture Transformation in Late Qing and Early Republic of China]. Journal of Shanxi University 2, 36: 22-26.

Geng, Chuanming. 2008. "Qingmo minchu wutuobang wenxue zonglun” [A Review of Utopian Literature in the Late Qing and Early Republican Period]. Chinese Social Sciences 4, 172: 176-190.

Huters, Theodore. 2005. Bringing the World Home: Appropriating the West in Late Qing and Early Republican China. Honolulu, HI: University of Hawai'i Press.

Isaacson, Nathaniel. 2017. Celestial Empire: The Emergence of Chinese Science Fiction. Middletown, CT: Wesleyan University Press.

Wang, David Der-wei. 1997. Fin-de-siècle Splendor: Repressed Modernities of Late Qing Fiction, 1849-1911. Stanford, CA: Stanford University Press.

Wang, Dun. 2012. "Cong Wanqing xiaoshuo xinshitouji diyihui kan shikong biaoshu de xiandai chonggou" [A Modern Reconstruction of Spatio-Temporal Representation from the First Chapter of the Late Qing Novel The New Story of the Stone]. Journal of Sun Yat-sen University (Social Science Edition) 3, 52: 38-43.

Wang, Ermin. 2003. Zhongguo xiandai sixiangshi [A History of Thought of Modern China]. Beijing: Social Sciences Academic Press.

Wang, Junnian. 2019. "The Annals of Wu Jianren." In Wujianren yanjiu ziliao huibian [A Compilation of Research Materials on Wu Jianren], ed. by Pei Xiuwei, 3-65. Harbin: Northern Literature and Arts Publishing House.

Wu, Jianren. [1908] 2016. Xinshitouji [The New Story of the Stone]. Hohhot: Inner Mongolia People's Publishing House.

Zhang, Zhongli, ed. 2008. Jindai shanghai chengshi yanjiu (1840-1949) [Urban Studies of Modern Shanghai (1840-1949)]. Shanghai: Shanghai Literature and Art Publishing House.

Zhou, Liyan. 2012. Wuyou zhiyi: minguo shiqi de wutuobang xiangxiang [The Significance of Utopia: Utopian Imagination in the Republican Period of China]. Hangzhou: Zhejiang University Press. 
Utopia. Shanghai. Late Qing dynasty. “The New Story of the Stone.” Wu Jianren.

The novel The New Story of the Stone (新石头记, Xinshitouji [1908] 2016), by Wu Jianren, is one of the most representative Chinese utopian works of the late Qing dynasty, or the early 20 th-century. The novel is evenly divided into two parts. The first 20 chapters probe into the political and social conditions of late Qing China through the depictions of the protagonist's travels to cities such as Shanghai, Wuhan and Beijing where the relations with the West had been established. The last 20 chapters, which are antithetical to the first part, depict a utopia - the Civilized World. There is a twisted mirror-image relationship between Shanghai and the Civilized World. The Civilized World alludes to civilized Shanghai with advanced hospitals, factories, museums, schools for women, trading markets and so on. Based on the image of Shanghai, the highly westernized and modernized Chinese metropolis, the author works out this "genuine civilized country" in the hope of competing with the "false civilized Western country". Therefore, by making the geographic location of "the Civilized World" both fictional and real, the author finds his way to imagining a unique Chinese utopia which might surpass the Western civilization in the late Qing China.

\author{
Prof. Dr. Yiping Wang \\ College of Literature and Journalism \\ Jiangan Campus \\ Sichuan University \\ Chuanda Road, Chengdu \\ Sichuan Province, 610207 \\ China \\ yipingwang@scu.edu.cn \\ ORCID: https://orcid.org/0000-0001-7961-9049
}

\author{
Prof. Dr. Ping Zhu \\ School of Foreign Languages and Literature \\ Suzhou University of Science and Technology \\ 99 Xuefu Road, Suzhou \\ Jiangsu Province, 215009 \\ China \\ zhuping@mail.usts.edu.cn
}

